\title{
Multilevel Analysis of Community Health Center, Performance of Health Personnel: Evidence from Ngawi, East Java
}

\author{
Rahayu Zulaikah",2), Didik Tamtomo3), Endang Sutisna Sulaeman3) \\ 1)District Health Office of Ngawi , East Java \\ 2)Masters Program in Public Health, Universitas Sebelas Maret \\ 3)Faculty of Medicine, Universitas Sebelas Maret, Surakarta
}

\section{ABSTRACT}

Background: Quality health services are one of the priorities and development goals in the health sector. Community Health Center as the first-line public services in the health sector are expected to provide quality services for the community. The quality of health services in community health center can be seen from the performance of the health personnel. This study aims to determine the factors that determine the performance of health personnel in health centers.

Subjects and Method: This study used an observational analytic method with a cross sectional approach. The study was conducted in 24 community health center in Ngawi, East Java on June-July 2019. The total sample of 216 health personnel of the community health center was selected based on proportional random sampling. The dependent variable of this study was the performance of health personnel. The independent variables in this study were accreditation status, education, income, work length, motivation, satisfaction, and workload. The data collections used questionnaires and were analyzed using multilevel linear regression test with Stata 13.
Results: The performance of health personnel significantly improved with good accreditation status ( $b=2.87 ; 95 \% \mathrm{CI}=0.03$ to $5.71 ; \mathrm{p}=0.048)$, high education $(\mathrm{b}=0.63 ; 95 \% \mathrm{CI}=0.13$ to $1.13 ; \mathrm{p}=$ o.013), and high workload $(b=0.86 ; 95 \% \mathrm{CI}=$ 0.34 to $1.39 ; \mathrm{p}=0.001)$. There was a contextual effect of the performance health personnel $(\mathrm{ICC}=$ $53.69 \%)$.

Conclusion: Good accreditation status, higher education and high work responsibilities increase the performance of the health personnel. There was a contextual effect of health centers on the health personnel.

Keywords: performance of health personnel, community health center, multilevel linear regression

\section{Correspondence:}

Rahayu Zulaikah. Ngawi Health Office, Jl. S. Parman 25 A, Ngawi, East Java. Email: dokterrahayu@yahoo.co.id.Mobile phone: 081946059306

Cite this as:

Zulaikah R, Tamtomo D, Sulaeman ES (2020). Multilevel Analysis of Community Health Center, Performance of Health Personnel: Evidence from Ngawi, East Java. J Health Policy Manage. 5(1): 13-22.

https://doi.org/10.26911/thejhpm.2020.05.01.02

Journal of Health Policy and Management is licensed under a Creative Commons Attribution-Non Commercial-Share Alike 4.o International License.

\section{BACKGROUND}

Quality health service is one of the determinants of the degree of public health in Indonesia. The National Medium-Term Development Plan (RPJMN) for 2015-2019 stated that one of the development goals in the health sector is improving access and quality of health services (Bapenas, 2014).
Uha (2012) stated that the current performance of public services is in the spotlight because the success or failure of an organization in carrying out its main tasks and functions can be seen from the achievements. Conceptually, performance can be seen from two aspects, namely the performance of individual employees and organizations. 
Likewise, the performance of community health center can be seen from the achievements of the institution's performance as well as from the performance of health personnel.

Gibson et al. (2012) revealed that there are three variables that affect performance, namely individual, psychological, and organizational variable. Individual factors include skills, abilities, work experience, family background, etc. Psychological factors include the role, perception, attitude, motivation and job satisfaction. While organizational factors include organizational structure, job design, type of leadership, reward system, organizational culture, and accreditation status in it.

Community health center accreditation is a form of recognition from independent institutions that have been established by the Minister of Health that the community health centers have performed services according to national standards. Community health center standards have been established by the ministry of health through the Minister of Health Regulation No. 75 of 2014, and community health center accreditation assessment instruments are stipulated in Minister of Health Regulation No. 46 of 2015 (Ministry of Health, 2015).

The data from Ministry of Health in health profile in 2018 reported that the number of community health center in East Java was 963 out of a total of 9845 throughout Indonesia. East Java Province is the province with the second largest number of community health center in Indonesia after West Java. Based on these privileges, East Java Province has the responsibility to foster the first-level health facilities in the region. East Java has 38 districts/cities, one of which is Ngawi (Ministry of Health, 2018).

A study by O'Beirne et al. (2012) explained that accreditation of health service facilities abroad (Canada, United States, United Kingdom, Netherlands, Denmark, Australia, and New Zealand) had an effect on performance of health personnel through efforts to improve quality, clearer quality assurance, an implementation for a better risk management, put more attention in patients' safety, and conduct better services for patients.

A study by Gusti et al. (2018) explained that work length, high motivation, better knowledge, complete facilities, strong leadership, and age are positively related to better performance on midwife profession.

Workload is another factor that affects the performance of health personnel from organizational variables. High workload is shown by the dual tasks that must be performed by health personnel. High workload is associated with increased work stress that can affect work motivation and decreased performance (Marfu'ah et al. 2016).

Another factor that affects performance is income. Income or incentives can affect the health personnel's performance because rewards can increase work motivation which ultimately directly increases performance to achieve high achievement. Likewise, there is supervision from superiors that fosters motivation to work better (Rusmitasari et al. 2018).

This study aims to analyze the contextual effect of community health center on health personnel's performance as well as other factors that affect the performance of health personnel.

\section{SUBJECTS AND METHOD}

\section{Study Design}

The design of this study used an observational analytic model with a cross sectional approach. This study was conducted at 24 community health centers in Ngawi, East Java on June-July 2019.

\section{Population and Sample}

The target population of this study was the health personnel of community health center in Ngawi, East Java. The sampling technique 
in this study used proportional random sampling and got a total sample of 216 health personnel.

\section{Study Variables}

The dependent variable in this study was the performance of health personnel. The independent variables were the health center accreditation status, education, income, work length, workload, motivation, and job satisfaction.

\section{Operational Definition of Variables} Performance of the health personnel could be interpreted as the results of work in quality and quantity in carrying out their duties in accordance with the responsibilities given to him. The tool used to collect data was questionnaires. The measurement scale was continuous, but for data analysis the scale was changed to a dichotomy.

Accreditation status was the level of accreditation graduation issued by the First Level Health Facilities Accreditation Commission (KA FKTP). The tool used to collect the data was in the form of community health center accreditation certificates. The measurement scale was categorical, but for data analysis it was changed to dichotomy.

Education was formal learning of knowledge, a skill acquired through teaching. The tool used to collect data was questionnaires. The scale of measurement was categorical, but for data analysis it was changed to dichotomy.

Income is the money received as a result of his work. The tool used to collect the data was a list of employee salaries. The measurement scale was continuous but for the purpose of data analysis it was changed to a dichotomy.

Workloads were tasks assigned by the head of the community health center to the health personnel to be completed within a certain period of time regarding additional tasks in addition to the main tasks that exist. The tool used to collect data was in the form of questi- onnaires. The measurement scale was continuous, but for data analysis it was changed to a dichotomy.

Motivation is an effort that can cause employees to be moved to do something to achieve their desired goals. The tool used to collect data using a questionnaire. The measurement scale is continuous, for the purpose of data analysis it is converted into a dichotomy. Work length was the period of time someone works at the health center in a matter of months. The tool used to collect data was in the form of questionnaires. The measurement scale was continuous data but for the purposes of data analysis it was changed to a dichotomy.

Job satisfaction was the psychological condition of someone who was pleasant when working at the health center for his assignment or role. The tool used to collect data was in the form of questionnaires. The measurement scale was continuous whereas for the purpose of data analysis it was changed to a dichotomy.

\section{Data Analysis}

Insert Univariate analysis aimed to describe the characteristics of each variable. Continuous data were described in n, Mean, SD, Min, Max. Categorical data were described in $\mathrm{n}$ and percent (\%).

The bivariate analysis was to determine the correlation between the performance of health personnel and the independent variables using chi-square test. Multivariate data analysis used multilevel linear regression analysis.

\section{Research Ethic}

The ethics of this study include consent, anonymity, confidentiality, and ethical eligibility. The ethical eligibility for this study came from the Health Research Ethics Commission of RSUD Dr. Moewardi with number: 738 / V / HERC / 2019. 


\section{RESULTS}

\section{A.Sample Characteristics}

Characteristics of the sample of the study in the form of continuous data were are pre- sented in table 1 , while the characteristics of categorical data were presented in table 2.

Table 1.Characteristics of the sample (continuous data)

\begin{tabular}{lccccc}
\hline \multicolumn{1}{c}{ Variable } & (n) & Mean & SD & Min. & Max. \\
\hline Income (x Rp 1,o0o) & 216 & 4,365 & 2,203 & 200 & 12,993 \\
Work length (month) & 216 & 161.73 & 111.41 & 2 & 414 \\
Workload & 216 & 1.78 & 0.93 & 1 & 5 \\
Motivation & 216 & 34.66 & 4.19 & 23 & 48 \\
Satisfaction & 216 & 14.41 & 2.31 & 8 & 26 \\
Performance & 216 & 36.07 & 5.36 & 24 & 48 \\
\hline
\end{tabular}

Table 2.Characteristics of the sample (categorical data)

\begin{tabular}{lcc}
\hline Characteristics & N & Percentage (\%) \\
\hline Accreditation status & 162 & 75 \\
Poor (basic-intermediate) & 54 & 25 \\
Good (primary) & & 60.65 \\
Education & 131 & 39.35 \\
Low(<Senior high school) & 85 & \\
High ( $\geq$ Senior high school) & & 43.52 \\
Income & 94 & 56.48 \\
Low & 122 & \\
High & & 43.98 \\
Work length & 95 & 56.02 \\
Short (<161 months) & 121 & 50.93 \\
Long ( $\geq 161$ months) & & 49.07 \\
Workload & 110 & 50.46 \\
Light $(<2)$ & 106 & 49.54 \\
Heavy $(\geq 2)$ & & \\
Motivation & 109 & 43.98 \\
Low (<34) & 107 & 56.02 \\
High $(\geq 34)$ & & \\
Satisfaction & 95 & 61.11 \\
Less satisfied $(<14)$ & 121 & 38.89 \\
Satisfied ( $\geq 14)$ & & \\
Performance & 132 & \\
Poor $(<36)$ & 84 & \\
Good $(\geq 36)$ & & \\
\hline
\end{tabular}

Employees with level of education $\geq$ Senior high school were more likely to perform well than those with education <Senior high school (OR=1.76; $\mathrm{p}=0.047)$, health personnel with workloads $\geq 2$ had a greater likelihood of good performance than health personnel with less workload $(\mathrm{OR}=2.54 ; \mathrm{p}=$ o.001), health personnel with high motiva- tion had a higher probability of better performance than health personnel with low motivation $(\mathrm{OR}=2.92 ; \mathrm{p}<0.001)$, and health personnel with high job satisfaction had a greater likelihood of good performance than health personnel with low satisfaction $(\mathrm{OR}=$ 2.91; $\mathrm{p}<0.001)$. 
Zulaikah et al./ Multilevel Analysis of Community Health Center

Table 3.The result of bivariate analysis from the factors that affect the performance of health personnel

\begin{tabular}{|c|c|c|c|c|c|c|c|c|}
\hline \multirow{3}{*}{ Variable Group } & \multicolumn{4}{|c|}{ Performance Assessment } & \multicolumn{2}{|c|}{ Total } & \multirow[t]{3}{*}{ OR } & \multirow[t]{3}{*}{$\mathbf{p}$} \\
\hline & \multicolumn{2}{|c|}{ Poor } & \multicolumn{2}{|c|}{ Good } & \multirow[b]{2}{*}{$\mathbf{N}$} & \multirow[b]{2}{*}{$\%$} & & \\
\hline & $\mathbf{N}$ & $\%$ & $\mathbf{N}$ & $\%$ & & & & \\
\hline \multicolumn{9}{|l|}{ Accreditation status } \\
\hline Poor (basic, intermediate) & 107 & 66.05 & 55 & 33.95 & 162 & 100.0 & 2.26 & 0.009 \\
\hline Good (primary) & 25 & 46.29 & 29 & 53.71 & 54 & 100.0 & & \\
\hline \multicolumn{9}{|l|}{ Education } \\
\hline Low (<Senior high school) & 87 & 66.41 & 44 & 33.59 & 131 & 100.0 & 1.76 & 0.047 \\
\hline High ( $\geq$ Senior high school) & 45 & 52.94 & 40 & 47.06 & 85 & 100.0 & & \\
\hline \multicolumn{9}{|l|}{ Income } \\
\hline Low & 64 & 68.09 & 30 & 31.91 & 94 & 100.0 & 1.69 & 0.065 \\
\hline High & 68 & 55.74 & 54 & 44.26 & 122 & 100.0 & & \\
\hline \multicolumn{9}{|l|}{ Work length } \\
\hline Short (<161 months) & 52 & 54.74 & 43 & 45.26 & 95 & 100.0 & 0.62 & 0.089 \\
\hline Long ( $\geq 161$ months) & 80 & 66.12 & 41 & 33.88 & 121 & 100.0 & & \\
\hline \multicolumn{9}{|l|}{ Workload } \\
\hline Light $(<2)$ & 79 & 71.82 & 31 & 28.18 & 110 & 100.0 & 2.54 & 0.001 \\
\hline Heavy $(\geq 2)$ & 53 & 50.0 & 53 & 50.0 & 106 & 100.0 & & \\
\hline \multicolumn{9}{|l|}{ Motivation } \\
\hline Low & 80 & 73.39 & 29 & 26.61 & 109 & 100.0 & 2.92 & $<0.001$ \\
\hline High & 52 & 48.60 & 55 & 51.40 & 107 & 100.0 & & \\
\hline \multicolumn{9}{|l|}{ Satisfaction } \\
\hline Low & 71 & 53.79 & 61 & 46.21 & 132 & 100.0 & 2.91 & $<0.001$ \\
\hline High & 24 & 28.57 & 60 & 71.43 & 84 & 100.0 & & \\
\hline
\end{tabular}

\section{B. The result of multivariate analysis}

Table 4 shows the results of multivariate analysis. There was an effect of accreditation status on the performance of heath personnel and was statistically significant. Heath personnel who work in community health center with good accreditation status had a log odd to perform well 2.87 units higher than heath personnel who work at community health center with low accreditation status $(\mathrm{b}=2.87$; $95 \% \mathrm{CI}=0.025$ to $5.71 ; \mathrm{p}=0.048$ ).

Highly educated heath personnel had logodd to perform well 0.36 units higher than low educated heath personnel $(b=0.36 ; 95 \%$ $\mathrm{CI}=0.016$ to $0.71 ; \mathrm{p}=0.040)$. Health personnel with high incomes had logodd to perform well 0.69 units higher than heath personnel with low income $(b=0.69 ; 95 \% \mathrm{CI}=-0.48$ to 1.87; $\mathrm{p}=0.246)$. Health personnel with long work length had logodd for good performance 0.002 units lower than heath personnel who had short work length $(b=-0.002 ; 95 \%$
$\mathrm{CI}=-0.007$ to $0.002 ; \mathrm{p}=0.393)$. Heath personnel who had heavy workloads had logodd to perform well 0.86 units higher than heath personnel who had light workloads $(b=$ $0.86 ; 95 \% \mathrm{CI}=0.34$ to $1.39 ; \mathrm{p}=0.001)$. Heath personnel who had high motivation had logodd to perform well 0.03 units higher than health personnel who had low motivation $(\mathrm{b}=$ 0.03 ; 95\% CI $=-0.103$ to $0.17 ; \mathrm{p}=0.646$ ). Satisfied heath personnel had logodd for good performance 0.69 units higher than unsatisfied heath personnel $(b=0.69 ; 95 \%$ $\mathrm{CI}=-0.41$ to $1.78 ; \mathrm{p}=0.218$ ).

The ICC value was $53.49 \%$, meaning that there was a contextual effect of the community health center on the performance of health personnel. Table 4 also shows that the LR test value vs. linear regression $p$ $<0.001$ which means that there was a significant difference between the multilevel linear regression analysis model and the usual linear regression analysis model. 
Table 4. The results of multilevel multiple logistic regression analysis of the factors affecting midwife performance

\begin{tabular}{|c|c|c|c|c|}
\hline \multirow[b]{2}{*}{ Independent Variable } & \multirow{2}{*}{$\begin{array}{c}\text { Coefficient } \\
\text { (b) }\end{array}$} & \multicolumn{2}{|c|}{$95 \% \mathrm{CI}$} & \multirow[b]{2}{*}{$\mathbf{p}$} \\
\hline & & $\begin{array}{l}\text { Lower } \\
\text { limit }\end{array}$ & $\begin{array}{l}\text { Upper } \\
\text { limit }\end{array}$ & \\
\hline \multicolumn{5}{|l|}{ Fixed Effect } \\
\hline Accreditation status (primary) & 2.87 & 0.03 & $5 \cdot 71$ & 0.048 \\
\hline Education ( $\geq$ Senior high school) & 0.36 & 0.02 & 0.71 & 0.040 \\
\hline Income (high) & 0.69 & -0.48 & 1.87 & 0.246 \\
\hline Work length ( $\geq 161$ months) & -0.002 & -0.007 & 0.003 & 0.393 \\
\hline Workload $(\geq 2)$ & 0.86 & 0.34 & 1.39 & 0.001 \\
\hline Motivation (High) & 0.03 & -0.11 & 0.17 & 0.646 \\
\hline Job satisfaction (high) & 0.69 & -0.41 & 1.78 & 0.218 \\
\hline \multicolumn{5}{|l|}{ Random Effect } \\
\hline \multicolumn{5}{|l|}{ Community health center } \\
\hline Var (Constanta) & 0.54 & 0.37 & 0.69 & \\
\hline $\mathrm{N}$ observation $=216$ & & & & \\
\hline $\mathrm{N}$ community health center $=24$ & & & & \\
\hline Log likelihood $=-591.81$ & & & & \\
\hline $\begin{array}{l}\text { LR test vs. Linear Regression, } \\
\mathrm{ICC}=53.69 \%\end{array}$ & & $\mathrm{p}<0.001$ & & \\
\hline
\end{tabular}

\section{DISCUSSION}

1. The effect of accreditation status on the performance of health personnel

The results show that there is a significant effect of the health center accreditation status on the performance of health personnel. Health personnel who work in community health center with good accreditation status have a logodd to perform well 2.87 units higher than health personnel who work at community health center with low accreditation status $(b=2.87 ; 95 \% \mathrm{CI}=0.025$ to 5.71 ; $\mathrm{p}=0.048$ ).

The results of this study are in line with a study conducted by Ensha (2018). According to O'Beirne et al. (2013), accreditation of health services abroad (Canada, United States, United Kingdom, Netherlands, Denmark, Australia and New Zealand) has an effect on efforts to improve quality, clearer quality assurance, better implementation of risk management, safety patients are given more attention by health personnel and services for patients become better.
2. The effect of education on the performance of health personnel

The results of this study indicate that there is an effect of education on the performance of health personnel and is statistically significant. Highly educated health personnel (>Senior high school) have a logodd to perform well 0.36 units higher than health personnel with low education $(b=0.36 ; 95 \% \mathrm{CI}=$ 0.016 to $0.71 ; \mathrm{p}=0.040$ ). The results of this study are in line with a study by Listyanti and Dewi, (2019) which stated that educational factors have a positive effect on health personnel performance.

3. The effect of income on the performance of health personnel

The analysis shows that there is an effect of income on the performance of health personnel, but it is not statistically significant. Health personnel with high income have a logodd to perform well 0.69 units higher than health personnel with low income $(b=0.69$; $95 \% \mathrm{CI}=-0.48$ to $1.87 ; \mathrm{p}=0.246)$. This study is in line with a study by Irwadi et al. (2019) and Zahara et al. (2011). 


\section{The effect of work length on the per- formance of health personnel}

The results of the analysis show that there is an effect of the length of service on the performance of health personnel but is not statistically significant. Health personnel with long work length have a logodd for good performance 0.002 units lower than health personnel with short work length $(\mathrm{b}=-0.002$; 95\% CI $=-0.007$ to $0.002 ; \mathrm{p}=0.393)$. The results of this study are not in line with a study conducted by Rusmitasari et al. (2018). In this study, long work length of more than 13 years can reduce health personnel's performance due to boredom that is caused by being too long in an organization. So, the health personnel are less enthusiastic and the performance is decreased. For those who are old physical abilities begin to decrease.

\section{The effect of workload on the per-} formance of health personnel

The analysis shows that there is an effect of workload on the performance of health personnel and is statistically significant. Health personnel with heavy workload have a logodd to perform well 0.86 units higher than health personnel who have low workload $(b=0.86$; $95 \% \mathrm{CI}=0.34$ to $1.39 ; \mathrm{p}=0.001)$. The results of this study are not in accordance with a study conducted by Sutarto et al. (2016). In his study, more workload does not reduce health personnel performance but rather increases health personnel performance. This can be explained that workload is a form of responsibility and participation of health personnel in their work, so that the health personnel who are given workloads feel that they get trust and responsibility from their superiors, this is conveyed by Gibson et al. (2012).

\section{The effect of motivation on the per- formance of health personnel}

There is a motivational effect on the performance of health personnel but is not statistically significant. Health personnel who have high motivation had a logodd to perform well 0.03 units higher than health personnel who have low motivation $(\mathrm{b}=0.03 ; 95 \% \mathrm{CI}=$ 0.103 to $0.17 ; \mathrm{p}=0.646$ ). The results of this study are in line with a study by Pundati et al. (2018) and Irwadi et al. (2018) which stated that work motivation has an effect on the performance of health personnel.

7. The effect of satisfaction on the performance of health personnel

There is an effect of job satisfaction on the performance of health personnel but is not statistically significant. Satisfied health personnel have a logodd for good performance o.69 units higher than unsatisfied health personnel $(b=0.69 ; 95 \% \mathrm{CI}=-0.41$ to 1.78 ; $\mathrm{p}=0.218$ ). The results of this study are in line with a study conducted by Rusmitasari et al. (2018) which stated that health personnel satisfaction has a direct effect on performance.

\section{The effect of community health cen- ter contextual on the performance of health personnel}

The analysis shows that the ICC value is $53.69 \%$ which means that there is a contextual effect of the health center on the performance of health personnel. The results of this study are in line with a study byGusti et al. (2018) which stated that there is a contextual effect of health center on the performance of midwives.

\section{AUTHOR CONTRIBUTION}

Rahayu Zulaikah asthe main researcher collected themes and analyzedthe data of the study; Didik Gunawan Tamtomo examined the contents of the study; Endang Sutisna Sulaeman examined the conceptual framework and methodology.

\section{CONFLICT OF INTEREST}

This study used fund from Ministry of Health's Human Resources Development Center (PPSDM). 


\section{FUNDING AND SPONSORSHIP}

There are no outside funds. The research costs are entirely from the main researcher.

\section{ACKNOWLEDGEIMENT}

We would like to thank the Head of the Ngawi District Health Office, the Head of Health Centers in the entire Ngawi Regency, and all health personnel who were willing to become the respondents, as well as fellow enumerators who helped us to collect the data.

\section{REFERENCE}

Badan Perencanaan Pembangunan Nasional Republik Indonesia (2014). Rencana pembangunan jangka menengah nasional 2015-2019. Jakarta: Kementerian Perencanaan Pembangunan Nasional Badan Perencanaan Pembangunan Nasional. Retrieved from http://www.bpkp.go.id/sesma/konten/2254/bukui-ii-dan-iii-rpjmn-2015-2019.bpkp

Ensha IS (2018). Pengaruh implementasi kebijakan akreditasi puskesmas terhadap manajemen pelayanan kesehatan masyarakat dalam mewujudkan produktivitas kerja, Jurnal Publik, 12: 1223. Retrieved from https://journal.uniga.ac.id/index.php/JPB/article/vi$\mathrm{ew} / 283$

Ghareeb A, Said H, Zoghbi ME (2018). Examining the impact of accreditation on aprimary healthcare organization in Qatar. BMC Medical Education. 18: 216. https://doi.org/10.1186/s12909018-1321-0

Gibson JL, Ivancevich JM, Donnelly JH. (2012). Organisasi, perilaku, struktur, dan proses. Jakarta: Binaputra Aksara

Gondokusumo S, Sutanto EM (2015). Motivasi, kepuasan kerja dan komitmen organisasional pegawai. Jurnal manajemen dankewirausahaan, 17(2):186-
196. https://doi.org/10.9744/jmk.17.2.196-206.

Gusti TE, Tamtomo D, Murti B (2019). Determinants of midwife performance on antenatal care in Surakarta and Karanganyar, Central Java. Journal of Health Policy and Manage. 3(1): 11-19. https://doi.org/10.26911/thejhpm.2018.03.01.02.

Hawari SIS, Banat NAE (2017). Impact of motivation on job performance of nursing staff in private hospitals in Jordan. Int. Journal of Academic Research in Accounting Finance \& Management Sciences. 7(2): 54-63. doi: 10.6007/IJARAFMS/v7-i2/2824

Irwadi, Zulfendri, Aulia D (2018). The associations of ward head direction and incentive with nurse performance at arun LNG hospital, Lhokseumawe, Aceh. J Health Policy Manage 3(2): 114117. https://doi.org/10.26911/thejhpm.2018.03.02.08.

Jayaweera T (2015). Impact of work environmental factors on job performance, mediating role of work motivation: A Study of hotel sectors in England. International Journal of Business and Management, 10(3): 271-278. doi: 10.5539/ijbm.-v1on3p271

Listyanti KL, Dewi SK (2019). Pengaruh motivasi berprestasi serta pendidikan dan pelatihan terhadap prestasi kerja. Jurnal Manajemen Udayana. 8 (8): 5285-5303.https://doi.org/10.24843/EJMUNUD.2019.vo8.io8.p23

Kemenkes RI (2014). Peraturan menteri kesehatan Republik Indonesia nomor 75 tahun 2014 tentang pusat kesehatan masyarakat. Jakarta: Kementerian Kesehatan Republik Indonesia. Retrieved from https://www.academia.edu/25399774/BUKU_SAKU_PERMENKES_N O._75_TAHUN_2014_TENTANG_PU SKESMAS?auto=download 
Kementerian Kesehatan RI (2018). Profil kementerian kesehatan tahun 2018. Jakarta: Kemenkes RI. Retrieved from https://pusdatin.kemkes.go.id/resources/download/pusdatin/profil-kesehatan-indonesia/Data-dan-Informasi_Profil-Kesehatan-Indonesia-2017.pdf Marfu'ah S, Tamtomo D, Suryono A (2016). Effect of psychological factors and workload on midwife performance in the integrated antenatal care in Pati, Central Java. J Matern Child Health, 1(3): 138-145. https://doi.org/10.26911/ thejmch.2016.01.03.01.

Mathis RL, Jackson JH (2009). Manajemen Sumber Daya Manusia, Edisi 10, Jakarta: Salemba Empat

Ministry of Health (2015). Peraturan menteri kesehatan no 46 tahun 2015. Akreditasi puskesmas, klinik pratama, tempat praktik mandiri dokter dan tempat praktik mandiri dokter gigi. Jakarta.

Mirshanti F, Tamtomo D, Murti B (2017). The associations between accreditation status, patient socio-economic factors, insurance type, patient per-ceived quality of service, and satisfaction at community health center. J Health Policy Manage, 2(1): 91-101.

Molyadi, Trisnantoro L (2017). Implementation of public health center accreditation policy in Kubu Raya district. Jurnal Kebijakan Kesehatan Indonesia 7: 18-23. Retrieved from https://journal.ugm.ac.id/jkki/article/view/25486/ 21518

Moorhead G (2013). Perilaku organisasi manajemen sumber daya manusia dan organisasi, Jakarta: Salemba Empat.

Murti B (2016). Prinsip dan metode riset epidemiologi, Edisi Keempat. Surakarta: Bintang Fajar Offset

O’Beirne M, Zwicker K, Sterling PD, Lait J, Robertson HL, Oelke ND (2013). The status of accreditaion in primary care.
Quality in primary care, 2(1):23-31. Retrieved from http://primarycare.imedpub.com/the-status-of-accreditation-in-primary-care.php?aid=214

Pundati TM, Tamtomo D, Sulaeman ES (2018). Motivation, workload and their association with nurse performance in dr. Arif Zainudin hospital Surakarta. J Health Policy Manage. 3:6370. https://doi.org/-10.26911/thejhpm.2018.o3.02.01

Rusmitasari H, Sulaeman ES, Murti B (2018). Predictors of work performance among nurses at PKU muhammadiyah hospital, Yogyakarta, J Health Policy Manage. 3(1): 41-46. https://doi.org/10.26911/thejhpm.2018.03.01.06

Seha HN, Tamtomo D, Sulaeman ES (2018). Does accreditation status effect job performance of electronic medical record clerks at community health center, J Health Policy Manage 3:56-62. https://doi.org/10.26911/thejhpm.2018.03.01.08

Simanjuntak S, Yustina I, Zulfendri (2019). The Association between motivation and sanction on hand hygiene compliance among nurses at Dr. Pirngadi Hospital, Medan, North Sumatera, J Health Policy Manage. 4(2):91-95 https://doi.org/10.26911/thejhpm.2019.04.02.03

Sutarto, Joebagjo H, Pawito (2016). Relationship between motivation, competence, workload and nurse performance at Dr Soediran Mangun Sumarso hospital, Wonogiri. J Health Policy Manage 1(2): 78-94. https://doi.org/10.26911/thejhpm.2016.01.02.03

Uha IN (2013). Budaya organisasi kepemimpinan dan kinerja. Kencana. Jakarta

Utami YT, Tamtomo D, Sulaeman ES (2018). Patient characteristic, financing type, accreditation status, and quality of 
health service at community health center, Surakarta, J Health Policy Manage. 2(1): 79-9o. https://doi.org/10.26911/thejhpm.2017.02.01.07

Kurniawan HK, Tamtomo D, Murti B (2019). Contextual effect of community health center on patient satisfaction of health care service in Ngawi, East Java. J Health Policy Manage, 4(1): 23-30. https://doi.org/10.26911/thejhpm.2019.04.01.03.

Utami RT, Ibrahim R (2015). Hubungan sikap profesional dengan kinerja perawat di RS PKU Muhammadiyah Yogya- karta. http://digilib.unisayogya.ac.id/id/eprint/152

Wahyuningsih RT (2015). Pengaruh kemampuan kerja, kompensasi dan motivasi terhadap kinerja perawat di instalasi rawat inap rumah sakit daerah Balung Kabupaten Jember Retrieved from http://repository.unej.ac.id/han dle/123456789/663322015-12-04

Zahara Y, Sitorus R, Sabri L (2011). Faktorfaktor motivasi kerja: Supervisi, penghasilan dan hubungan interpersonal memengaruhi kinerja perawat pelaksana. Jurnal Keperawatan Indonesia. 14(2):73-82 doi:10.7454/jki.v14i2.312. 